\title{
Tocopherols and Antioxidants Assay to Understand the Mechanism of Soybean Seed Longevity
}

\author{
Sooganna ${ }^{1}$, S.K. Jain ${ }^{2}$, Amrit Lamichaney $^{3}$, Supradip Saha ${ }^{4}$, Anjali Anand ${ }^{5}$, S.K. Lal ${ }^{6}$
}

10.18805/LR-4516

\begin{abstract}
Background: Soybean, an important oilseed crop of India, is rich in protein, oil, vitamins, isoflavones and minerals. Being an oilseed crop and the inherent physiological and biochemical properties, soybean seeds looses itsviability andvigour rapidly during storage, resultinginto poor stand establishment and productivity, upon subsequent planting. The current study aimed to understand the mechanism of antioxidants and antioxidant enzymes in soybean seed longevity.

Methods: Ten good storer and ten poor storer, identified after storing for 8 months in ambient laboratory condition, were phenotyped biochemically to understand the mechanism of antioxidants [tocopherols (4 isomers) and isoflavones (12 isomers)] and antioxidant enzymes [catalase (CAT), peroxidise (POX), superoxidedismutase (SOD) and glutathione reductase (GR)]in seed longevity.

Result: Good and poor storer genotypes recorded a mean initial germination of 99 and $96 \%$, decreased to 91 and $67 \%$, respectively upon eight months of laboratory ambient storage. Significant differences were observed in the activities of SOD, CAT, GR, alpha ( $\alpha-$ T) and delta $(\delta-T)$ tocopherol between good and poor storer genotypes. Isomers of tocopherols ie. $\alpha$-T and $\delta$-T were found to beeither negatively $(r=-0.55)$ or positively $(r=0.60)$ associated with seed longevity, indicated the role of individual tocopherol isomer than those to total tocopherols in seed longevity.
\end{abstract}

Key words: Antioxidants, Enzymes, Isomers, Soybean, Seed longevity, Tocopherols.

\section{INTRODUCTION}

Soybean [Glycine max (L.) Merrill], a major oilseed crop in India, also rich in proteins, vitamins, isoflavones and minerals, is very common fulfilling the nutritional requirement of vegetarians. Owing to its high oil and protein contents, the seeds have poor storability. Majority of the soybean are grown in an area having higher temperature and relative humidity, congenial for acceleration of seed deterioration, resulting into poor field stand and productivity upon planting (Singh and Ram, 1986). Though soybean, in general, is among least storable group (Justice and Bass, 1978), existence of genetic variation in storability was reported (Hosamani, 2013). Gowda (2017) reported an association of seed coat colour and seed size (100-seed weight) with seed storability in soybean; black seeded genotypes were better storers. Similarly, association of seed coat colour with seed quality had been reported in chickpea and mungbean crops (Lamichaney et al., 2016; Lamichaney and Katiyar, 2017; Lamichaney et al., 2018). In soybean, free radical mediated or enzymatic peroxidation of PUFA were reported to play an important role in seed deterioration. Production and accumulation of free radicals or reactive oxygen species due to lipid peroxidation caused rapid loss of seed viability and vigour by disturbing cellular integrity (Corbineau et al., 2002). By scavenging the free radicals cell protects itself and maintains cellular integrity. The most important mechanism of scavenging free radicals is via antioxidants (vitamin E or tocopherols, isoflavones) or antioxidant enzymes (SOD, CAT, POX, GR), which lowers the content of free radicals and maintain seed viability and vigour during storage; their role during storage is inconsistent (Hosamani
${ }^{1}$ ICAR-Indian Institute of Millets Research, Hyderabad-500 030, Telangana, India.

${ }^{2}$ Division of Seed Science and Technology, ICAR-Indian Agricultural Research Institute, New Delhi-110 012, India.

${ }^{3}$ Division of Crop Improvement, ICAR-Indian Institute of Pulses Research, Kanpur-208 024, Uttar Pradesh, India.

${ }^{4}$ Division of Agriculture Chemicals, ICAR-Indian Agricultural Research Institute, New Delhi-110 012, India.

${ }^{5}$ Division of Plant Physiology, ICAR-Indian Agricultural Research Institute, New Delhi-110 012, India.

${ }^{6}$ Division of Genetics, ICAR-Indian Agricultural Research Institute, New Delhi-110 012, India.

Corresponding Author: Sooganna, ICAR-Indian Institute of Millets Research, Hyderabad-500 030, Telangana, India.

Email: sooganna@millets.res.in

How to cite this article: Sooganna, Jain, S.K., Lamichaney, A., Saha, S., Anand, A. and Lal, S.K. (2021). Tocopherols and Antioxidants Assay to Understand the Mechanism of Soybean Seed Longevity. Legume Research. DOI: 10.18805/LR-4516.

Submitted: 26-09-2020 Accepted: 16-03-2021 Online: 24-04-2021

et al., 2013). Therefore, the present study wasconducted to understand the mechanism of antioxidants (isomer) and/or antioxidant enzyme(s) association with seed longevity on chosensoybean genotypes.

\section{MATERIALS AND METHODS Experimental materials}

From the previous investigations (Sooganna et al., 2016), from 59 soybean genotype screened for seed storability [loss 
of germination under laboratory ambient storage (average $25 \pm 2^{\circ} \mathrm{C}$ and $\left.65 \pm 5 \% \mathrm{RH}\right)$ ], ten genotypes each from good and poor storers were chosen for further biochemical assays (Table 1).The study was carried out during the period of 2014-2015 in the Division of Seed Science and Technology, ICAR-Indian Agricultural Research Institute, New Delhi.

\section{Standard germination}

One hundred pure seeds placed in between moist germination paper, rolled and covered by blotter paper to avoid moisture loss, were incubated in dark for seven days at $25^{\circ} \mathrm{C}$. On eighth day from incubation, individual seeds/ seedlings were examined and categorized into normal seedlings, abnormal seedlings; hard seeds and dead seedsfollowing ISTA rules (Anon, 2015). Only the percentage of normal seedlings wasconsideredto calculate germination values.

\section{Biochemical assay from seeds}

For the assay of antioxidant enzymes, one gram of soybean seeds were homogenized in $100 \mathrm{mM}$ potassium phosphate buffer $(\mathrm{pH} 7.8)$ with a pinch of poly vinyl pyrrolidone and centrifuged at $15000 \mathrm{rpm}$ for $10 \mathrm{~min}$ at $4^{\circ} \mathrm{C}$. The supernatant was collected and used for enzyme assays viz. peroxidase (POX), glutathione reductase (GR), superoxidedismutase (SOD) and catalase (CAT). The SOD activity was quantified following Beauchamp and Fridovich (1971). The CAT activity was measured following Aebi (1984). The (POX) activity was assayed (as increase in optical density due to oxidation of guaiacol to tetra-guaiacol) following Castillo et al. (1994). The GR activity was determined at $25^{\circ} \mathrm{C}$ and $340 \mathrm{~nm}$ (the rate of NADPH oxidation) following Smith et al. (1988). Estimation of tocopherols was done using HPLC (Saha et al., 2013). C30 column was used as the stationary phase. Separation was accomplished by using $100 \%$ methanol at a flow rate of $1.0 \mathrm{ml} / \mathrm{min}$ for $20 \mathrm{~min}$. Column oventemperature was maintained at $40^{\circ} \mathrm{C}$. Resolution of tocopherols was detected at $295 \mathrm{~nm}$ using a PDA detector. One gram of finely ground soybean flour was added in $20 \mathrm{ml}$ of acetone and subjected to sonication for $10 \mathrm{~min}$ and left overnight for extraction. The sample was filtered using Whatman filter paper and $10 \mathrm{ml}$ acetone was added and again subjected tosonication. The sample was filtered with Whatman filter paper and filtrate was subjected to rotary evaporator. $20 \mu \mathrm{l}$ of the filtrate was injected into HPLC and allowed to run for $20 \mathrm{~min}$. The amount of different isomers of tocopherols $(\alpha$, $\beta, \gamma$ and $\delta$ ) present in the sample was estimated by putting the value of peak area of sample into the equation derived from the standard graph and expressed in $\mu \mathrm{g} / \mathrm{g}$ sample. Isoflavones were also estimated using HPLC. C18 column was used as a non-polar stationary phase. A binary gradient of $0.1 \%$ formic acid in acetonitrile ( $13 \%$ : solvent $A$ ) and $0.1 \%$ formic acid in water (87\%: solvent B) was used as mobile phase, run using the following time programme (\% solvent $\mathrm{A} /$ solvent B): 0min (0/100), $5 \mathrm{~min}(10 / 90), 20 \mathrm{~min}(0 / 100)$ and $50 \mathrm{~min}(0 / 100)$. The flow rate of mobile phase was $0.75 \mathrm{ml} /$ min for $50 \mathrm{~min}$. Column oven temperature was maintained at $40^{\circ} \mathrm{C}$. The resolution of isoflavones was detected at $260 \mathrm{~nm}$ using a PDA detector.One gram of finely ground soybean flourwas extracted with $20 \mathrm{ml}$ of $80 \%$ methanol and subjected to ultra-sonication for $35 \mathrm{~min}$ and centrifuged at

Table 1: List of soybean seed genotypes and their characteristics.

\begin{tabular}{|c|c|c|c|c|c|c|}
\hline \multirow[b]{2}{*}{ Genotypes } & \multirow[b]{2}{*}{ Seed colour } & \multirow[b]{2}{*}{ Hilum colour } & \multirow{2}{*}{$\begin{array}{c}100 \text {-seed } \\
\text { weight } \\
(\mathrm{g})\end{array}$} & \multicolumn{2}{|c|}{ Germination (\%) } & \multirow[b]{2}{*}{ Storability } \\
\hline & & & & $\begin{array}{l}\text { Fresh } \\
\text { seeds }\end{array}$ & $\begin{array}{l}\text { Eight months } \\
\text { stored seeds }\end{array}$ & \\
\hline AMSS-34 & Black & Grey & 6.5 & 100 & 95 & Goodstorer \\
\hline DS-74 & Black & Grey & 6.7 & 99 & 93 & Goodstorer \\
\hline EC-13969 & Yellow & Grey & 6.9 & 98 & 92 & Goodstorer \\
\hline G-2253 & Black & Grey & 6.5 & 99 & 91 & Goodstorer \\
\hline G-2603 & Black & Grey & 7.2 & 97 & 92 & Goodstorer \\
\hline G-2614 & Black & Brown & 6.5 & 99 & 90 & Goodstorer \\
\hline G-2651 & Black & Brown & 6.7 & 97 & 91 & Goodstorer \\
\hline$M-253$ & Black & Grey & 6.5 & 98 & 90 & Goodstorer \\
\hline M-11913 & Black & Grey & 7.0 & 100 & 90 & Goodstorer \\
\hline MACS-1311 & Yellow & Brown & 6.8 & 98 & 89 & Goodstorer \\
\hline P-250 & Yellow & Brown & 9.2 & 96 & 70 & Poorstorer \\
\hline P-876 & Yellow & Brown & 7.6 & 97 & 68 & Poorstorer \\
\hline PS-1480 & Yellow & Brown & 10.0 & 98 & 66 & Poorstorer \\
\hline JS(SH)-93-37 & Black & Brown & 11.2 & 95 & 70 & Poorstorer \\
\hline DSB-19 & Yellow & Brown & 14.0 & 97 & 65 & Poorstorer \\
\hline VLS-81 & Yellow & Brown & 14.0 & 95 & 64 & Poorstorer \\
\hline AMS-56 & Yellow & Brown & 12.4 & 95 & 65 & Poorstorer \\
\hline MAUS 608 & Yellow & Brown & 14.2 & 98 & 66 & Poorstorer \\
\hline KBS-2011 & Yellow & Grey & 12.7 & 95 & 68 & Poorstorer \\
\hline DS-2708 & Yellow & Brown & 12.5 & 98 & 69 & Poorstorer \\
\hline
\end{tabular}


$13,000 \mathrm{rpm}$ for $5 \mathrm{~min}$. The supernatant was filtered first with

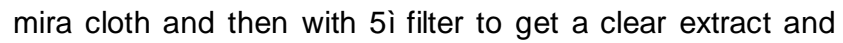
subjected to rotary evaporator for $3-5 \mathrm{~min}$. Methanol was added on the extract to make up the volume to $5 \mathrm{ml}$. $20 \mathrm{il}$ of this sample extract was injected into the HPLC column inlet and allowed to run for $50 \mathrm{~min}$. The amount of different isomers of isoflavones present in the sample was estimated by putting the values of peak area of sample into the equation derived from the standard graph and expressed in ig $/ \mathrm{g}$ sample. The level of lipid peroxidation was measured in terms of thiobarbituric acid reactive substances (TBARS) content (Ohkawa et al., 1979).

To normalize the data,the percent germination values were subjected to arcsine transformation and statistical analysis was done using SPSS software.

\section{RESULTS AND DISCUSSION}

All the studied twenty genotypes had an initial germination $\geq 95 \%$; of these, only good storer, but eight months stored genotypes (seeds), maintained higher germination value $>89 \%$ with a mean germination value of $91.3 \%$. In contrast, the germination values among poor storer, also eight months stored genotypes (seeds), declined drastically $(<70 \%)$ with a mean value of $67.1 \%$ (Table 1). In general, good storer genotypes were black with exceptions [EC-13969 and MACS-1311 (yellow)] andsmaller in sizewith a mean 100seed weight of $6.7 \mathrm{~g}$, whereas the poor storer genotypes were yellow with an exception [JS(SH)-93-37 (black)] andlarge with amean 100-seed weight of $11.8 \mathrm{~g}$ (Table 1). Similar association of seed storability with seed colour, seed size and weight had been reported previously by Hosamani (2013) and Gowda (2017) in soybean. Small size seeds have thick and higher proportion of seed coat (Gowda, 2017; Lamichaney et al. 2016; Lamichaney et al. 2017); the interface between the embryo and the external environment helps in maintaining seed viability during storage. Further, pigmentation in seeds, imparted by tannins and phenols (Caldes and Blair, 2009; Gowda, 2017), known to have antimicrobial properties (Farahin et al. 2016); higher contents of such compounds in black genotypes protects the seeds from fungal and insect attacks during storage and helps in maintaining seed longevity.

In the present investigation, MDA contents, a product of lipid peroxidation, ranged between 141.9 to 238.7 (nM/g seed) with a mean value of $190.4(\mathrm{nM} / \mathrm{g}$ seed) among good storers, whereas between 225.8 to 434.8 (nM/g seed) with a mean value of $328.1(\mathrm{nM} / \mathrm{g}$ seed) among poor storers (Table 2). A significant, but negative correlation betweenMDA

Table 2: Antioxidant enzymes and volatile aldehydes among soybean genotypes.

\begin{tabular}{|c|c|c|c|c|c|}
\hline Genotypes & $\begin{array}{c}\text { SOD }(\text { Units/ } \\
\mathrm{min} / \mathrm{g} \\
\text { seed })\end{array}$ & $\begin{array}{l}\text { CAT }(\mu \text { moles } \\
\mathrm{H}_{2} \mathrm{O}_{2} / \mathrm{min} / \mathrm{g} \\
\text { seed })\end{array}$ & $\begin{array}{c}\text { POX } \\
(\mu \mathrm{moles} / \mathrm{min} / \mathrm{g} \\
\text { seed })\end{array}$ & $\begin{array}{c}\mathrm{GR}(\mu \mathrm{moles} \\
\mathrm{NADPH} / \mathrm{min} / \mathrm{g} \\
\text { seed })\end{array}$ & $\begin{array}{c}\text { MDA contents } \\
(\mathrm{nM} / \mathrm{g} \\
\text { seed })\end{array}$ \\
\hline \multicolumn{6}{|l|}{ Good storer } \\
\hline AMSS-34 & 9.6 & 17.6 & 6.3 & 3.1 & 161.0 \\
\hline DS-74 & 8.4 & 17.1 & 3.2 & 3.0 & 232.3 \\
\hline EC-13969 & 7.5 & 12.3 & 3.3 & 2.5 & 187.1 \\
\hline G-2253 & 9.3 & 14.2 & 4.9 & 2.4 & 171.3 \\
\hline G-2603 & 9.8 & 13.2 & 3.2 & 2.6 & 235.5 \\
\hline G-2614 & 8.4 & 14.3 & 1.5 & 2.0 & 206.8 \\
\hline G-2651 & 9.1 & 18.1 & 4.3 & 2.8 & 164.5 \\
\hline M-253 & 9.4 & 16.2 & 3.3 & 2.5 & 141.9 \\
\hline M-11913 & 9.2 & 16.4 & 4.9 & 2.8 & 164.5 \\
\hline MACS-1311 & 7.8 & 11.5 & 3.4 & 2.2 & 238.7 \\
\hline \multicolumn{6}{|l|}{ Poor storer } \\
\hline P-250(129) & 5.3 & 8.6 & 1.3 & 1.0 & 335.5 \\
\hline P-876(146) & 4.8 & 8.2 & 4.0 & 1.6 & 312.9 \\
\hline PS-1480 & 4.1 & 11.4 & 3.1 & 1.4 & 225.8 \\
\hline JS(SH)-93-37 & 6.6 & 11.6 & 5.1 & 1.7 & 290.3 \\
\hline Dsb-19 & 2.7 & 8.6 & 2.7 & 1.2 & 320.3 \\
\hline VLS-81 & 5.3 & 10.3 & 3.9 & 0.8 & 358.1 \\
\hline AMS-56 & 2.7 & 7.1 & 2.8 & 1.3 & 322.6 \\
\hline MAUS 608 & 3.6 & 6.3 & 2.1 & 1.3 & 348.4 \\
\hline KBS-2011 & 5.6 & 7.5 & 4.4 & 1.0 & 434.8 \\
\hline DS-2708 & 3.8 & 8.6 & 2.0 & 1.2 & 332.3 \\
\hline $\operatorname{LSD}(P<0.05)$ & 1.4 & 3.4 & 1.3 & 1.0 & 54.0 \\
\hline Mean (good storer) & 8.8 & 15.1 & 3.8 & 2.6 & 190.4 \\
\hline Mean (poorstorer) & 4.5 & 8.8 & 3.1 & 1.2 & 328.1 \\
\hline Grand mean & 6.6 & 12.0 & 3.5 & 1.9 & 259.2 \\
\hline
\end{tabular}


content andseed germination [fresh $(r=-0.71)$ and eight months stored seeds $(r=-0.84)$ substantiated the previous statement of lipid peroxidation as a major cause of seed deterioration in soybean (Table 5).

Free radical scavenging by antioxidants viz. SOD, CAT, $\mathrm{GR}$, tocopherols and isoflavones, etcalleviate the damage to lipid membranes caused by free radicals and leads to greater seed longevity (Lehner et al. 2008; Hameed et al.2014; Gowda, 2017). The present investigation with chosen good and poor storer soybean genotypes validated the role of antioxidants. Marked differences were observed between good and poor storer genotypes in SOD activity, ranged between $7.5 \mathrm{Units} / \mathrm{min} / \mathrm{g}$ seed (EC-13969) to $9.8 \mathrm{Units} / \mathrm{min} / \mathrm{g}$ seed (G-2603) with a mean value of $8.8 \mathrm{Units} /$ $\mathrm{min} / \mathrm{g}$ seed among good storer genotypes, whereas 2.7 Units $/ \mathrm{min} / \mathrm{g}$ seed (Dsb 19 and AMS-56) to $6.6 \mathrm{Units} / \mathrm{min} / \mathrm{g}$ seed[JS(SH)-93-37] with a mean value of $4.5 \mathrm{Units} / \mathrm{min} / \mathrm{g}$ seed among poor storer genotypes (Table 2). These findings were further substantiated by a significant and strong positive association $(r=0.93)$ between SOD activity and germination from eight months stored seeds (Table 5). Likewise, the CAT activities among good storer genotypes were higher $>11 \mu$ moles $\mathrm{H}_{2} \mathrm{O}_{2} / \mathrm{min} / \mathrm{g}$ seedwith a mean value of $15.1 \mu$ moles $\mathrm{H}_{2} \mathrm{O}_{2} / \mathrm{min} / \mathrm{g}$ seed, whereas among poor storer genotypes were lower $<10 \mu$ moles $\mathrm{H}_{2} \mathrm{O}_{2} / \mathrm{min} / \mathrm{g}$ seedwith exceptions[PS-1480, JS(SH)-93-97 and VLS-81] having a mean value of $8.8 \mu$ moles $\mathrm{H}_{2} \mathrm{O}_{2} / \mathrm{min} / \mathrm{g}$ seed (Table 2).Catalase also showed a positive association $(r=0.86)$ with germination from eight months stored seeds(Table 5). Peroxidase activities, among good storer genotypes, ranged between 1.5 to $6.3 \mu \mathrm{moles} / \mathrm{min} / \mathrm{g}$ seedwith a mean value of $3.8 \mu \mathrm{moles} / \mathrm{min} / \mathrm{g}$ seed,whereas among poor storers ranged between 1.3 to $5.2 \mu \mathrm{moles} / \mathrm{min} / \mathrm{g}$ seed with a mean value of $3.1 \mu \mathrm{moles} / \mathrm{min} / \mathrm{g}$ seed (Table 2). The activities of GR ranged between 2.0to $3.1 \mu \mathrm{moles} \mathrm{NADPH} / \mathrm{min} / \mathrm{g}$ seed and 0.8 to $1.7 \mu \mathrm{moles} \mathrm{NADPH} / \mathrm{min} / \mathrm{g}$ seedamong good and poor storer genotypes, respectively (Table 2). GR activity also showed a positive and strong association $(r=0.94)$ with seed germination from eight months stored seeds (Table 5).

Tocopherols are known to have a free radical scavenging potential owing to its chromanol ring (Liebler, 1993). The content of total tocopherols and its different homologues derived are given (Table 3 ). The dominant tocopherol in soybean genotypes, as recorded, were $\gamma-T$, accounted for $69 \%$ of the total tocopherols, followed by $\delta-T$ (29\%), $\alpha-T(0.9 \%)$ and $\alpha-T(0.4 \%)$. Chen et al. (2015) had reported the relation of total tocopherols with soybean seed longevity, whereas the present findings had focused on the

Table 3: Tocopheroland its homologues among soybean genotypes.

\begin{tabular}{|c|c|c|c|c|c|}
\hline \multirow[b]{2}{*}{ Genotypes } & \multicolumn{5}{|c|}{ Tocopherol and its homologues ( $\mu \mathrm{g} / \mathrm{g}$ seed) } \\
\hline & $\alpha-T$ & $\beta-T$ & $\gamma-\mathrm{T}$ & $\delta-\mathrm{T}$ & Total tocopherols \\
\hline \multicolumn{6}{|l|}{ Good storer } \\
\hline AMSS-34 & 1.1 & 0.5 & 282.3 & 132.4 & 416.3 \\
\hline DS-74 & 2.7 & 1.6 & 268.5 & 155.2 & 427.9 \\
\hline EC-13969 & 1.8 & 0.6 & 266.6 & 129.5 & 398.6 \\
\hline G-2253 & 1.7 & 0.7 & 260.5 & 117.4 & 380.3 \\
\hline G-2603 & 2.4 & 0.6 & 332.4 & 188.0 & 523.3 \\
\hline G-2614 & 2.7 & 0.9 & 270.6 & 146.8 & 421.0 \\
\hline G-2651 & 2.8 & 0.5 & 278.6 & 130.6 & 412.4 \\
\hline$M-253$ & 0.6 & 3.5 & 144.8 & 92.9 & 241.7 \\
\hline$M-11913$ & 0.0 & 1.4 & 104.3 & 68.2 & 174.0 \\
\hline MACS-1311 & 2.2 & 1.4 & 275.6 & 102.7 & 381.9 \\
\hline \multicolumn{6}{|l|}{ Poor storer } \\
\hline P-250(129) & 7.7 & 0.6 & 311.5 & 109.7 & 429.5 \\
\hline P-876(146) & 0.4 & 0.2 & 70.2 & 49.6 & 120.4 \\
\hline PS-1480 & 0.5 & 3.6 & 96.4 & 62.6 & 163.0 \\
\hline $\mathrm{JS}(\mathrm{SH})-93-37$ & 5.1 & 1.7 & 282.0 & 107.5 & 396.3 \\
\hline Dsb-19 & 3.7 & 0.6 & 353.9 & 110.0 & 468.2 \\
\hline VLS-81 & 7.0 & 1.7 & 295.9 & 93.3 & 397.9 \\
\hline AMS-56 & 6.7 & 0.5 & 356.9 & 107.5 & 471.5 \\
\hline MAUS 608 & 4.5 & 0.7 & 343.7 & 100.0 & 449.0 \\
\hline KBS-2011 & 2.8 & 4.1 & 154.1 & 52.5 & 213.6 \\
\hline DS-2708 & 10.0 & 1.1 & 272.6 & 65.9 & 349.6 \\
\hline $\operatorname{LSD}(P<0.05)$ & 2.3 & 1.2 & 6.2 & 4.6 & 5.9 \\
\hline Mean (goodstorer) & 1.8 & 1.2 & 248.4 & 126.4 & 377.7 \\
\hline Mean (poorstorer) & 4.8 & 1.5 & 253.7 & 85.9 & 345.9 \\
\hline Grand mean & 3.3 & 1.3 & 251.1 & 106.1 & 361.8 \\
\hline
\end{tabular}




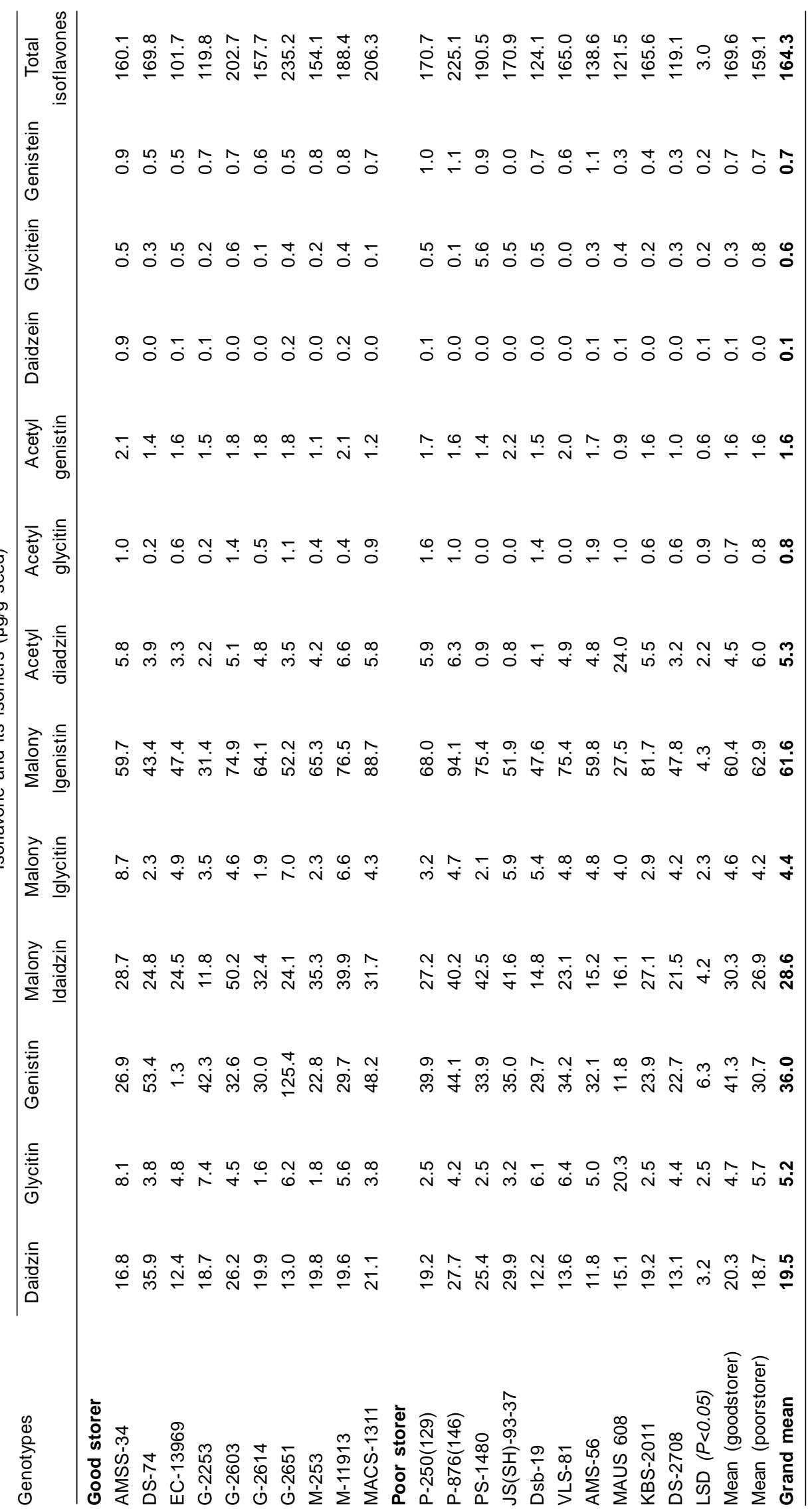


Tocopherols and Antioxidants Assay to Understand the Mechanism of Soybean Seed Longevity

proportions of individual tocopherol homologues among different soybean genotypes having contrasting longevity. Poor storers recorded more tocopherol contents of $\alpha-T, \beta-T$ and $\gamma$-T than those to good storers, which recorded higher $\delta$-T and total tocopherols. $\alpha-\mathrm{T}, \beta-\mathrm{T}, \gamma$-T and $\delta$-T among poor storers recorded a mean values of $4.8,1.5,253.7$ and $85.9 \mu \mathrm{g} / \mathrm{g}$ seed, whereas $1.8,1.2,248.4$ and $126.4 \mu \mathrm{g} / \mathrm{g}$ seed among good storers. Total tocopherols among good storers ranged between174.0 (M-11913) to $523.3 \mu \mathrm{g} / \mathrm{g}$ seed (G2603) with a mean value of $377.7 \mu \mathrm{g} / \mathrm{g}$ seed, and among poor storers between 120.4 [P-876(146)] to $468.2 \mu \mathrm{g} / \mathrm{g}$ seed (Dsb-19) with a mean value of $345.9 \mu \mathrm{g} / \mathrm{g}$ seed (Table 3 ). None of the tocopherol homologues could establish a significant correlation with germination in fresh seeds, whereas the germination from eight months stored seeds recorded a negative association $(r=-0.55)$ with $\alpha-T$ and positive association $(r=0.60)$ with $\delta$-T (Table 5), implying its role in maintaining seed longevity. A similar negative association of $\alpha-T$ with seed longevity was reported by Lee et al. (2017) in rice. Mutants with faulty tocopherol cycle in Arabidopsisfailed to maintain seed viability for longer period due to its inability to scavenge the free radicals produced

Table 5: Correlation coefficients between seed longevity (germination\%) and variousbiochemical parameters.

\begin{tabular}{|c|c|c|}
\hline \multirow[b]{2}{*}{ Parameter } & \multicolumn{2}{|c|}{ Germination (\%) } \\
\hline & $\begin{array}{l}\text { Fresh } \\
\text { seeds }\end{array}$ & $\begin{array}{l}\text { Eight months } \\
\text { stored seeds }\end{array}$ \\
\hline \multicolumn{3}{|c|}{ Antioxidant enzyme } \\
\hline SOD & 0.52 & $0.93^{*}$ \\
\hline Catalase & 0.61 & $0.86^{*}$ \\
\hline Peroxidase & 0.13 & 0.31 \\
\hline GR & 0.69 & $0.94^{*}$ \\
\hline \multicolumn{3}{|l|}{ Volatile aldehyde } \\
\hline MDA & -0.71 & $-0.84^{*}$ \\
\hline \multicolumn{3}{|l|}{ Tocopherol } \\
\hline$\alpha-T$ & -0.52 & $-0.55^{\star}$ \\
\hline$\beta-T$ & -0.17 & -0.17 \\
\hline$\gamma-\mathrm{T}$ & -0.22 & -0.03 \\
\hline$\delta$ - $\mathrm{T}$ & 0.19 & $0.60^{*}$ \\
\hline Total tocopherols & -0.12 & 0.15 \\
\hline \multicolumn{3}{|l|}{ Isoflavone } \\
\hline Daidzin & 0.11 & 0.18 \\
\hline Glycitin & 0.17 & -0.14 \\
\hline Genistin & -0.07 & 0.22 \\
\hline Malonyldaidzin & 0.05 & 0.20 \\
\hline Malonylglycitin & 0.06 & 0.15 \\
\hline Malonylgenistin & -0.22 & -0.09 \\
\hline Acetyl diadzin & 0.10 & -0.19 \\
\hline Acetyl glycitin & -0.21 & -0.12 \\
\hline Acetyl genistin & -0.17 & 0.14 \\
\hline Daidzein & 0.43 & 0.37 \\
\hline Glycitein & 0.08 & -0.24 \\
\hline Genistein & 0.13 & 0.01 \\
\hline Total isoflavones & -0.09 & 0.15 \\
\hline
\end{tabular}

as a result of lipid peroxidation (Sattler et al. 2004). KamalEldin and Appelqvist (1996) demonstrated the role of $\alpha$ tocopherol to have a strong antioxidant capacity,whereas, Jiang (2014) and Kim (2014) reported $\gamma$ - and $\delta$-tocopherolsto have betterantioxidant activities than those to $\alpha$-tocopherol. In the present study, the association of tocopherols with seed longevity was found to be inconsistent, as some reports showed correlation of tocopherol with seed longevity and some did not (Priestley et al. 1980; Simontacchi et al. 1993; Sattler et al., 2004).

Isoflavones are reported to have various physiological properties like antioxidants, anti-inflammatory, anti-tumour, and anti-aging (Wang et al., 2013). Twelve different isomers of Isoflavones were found in soybean namely,daidzein, genistein,glycitein, daidzin, genistin, glycitin, acetyldaidzin, acetylgenistin, acetylglycitin, malonyldaidzin, malonylgenistin and malonylglycitin. Genetic variation with isoflavones was reported in soybean, influenced by environment and storage period (Lee et al., 2003). In the present investigation, Isoflavones among good storer genotypes ranged between 102.1 to $236 \mu \mathrm{g} / \mathrm{g}$ seedwith a mean value of $170.1 \mu \mathrm{g} / \mathrm{g}$ seed, whereas among poor storer genotypes it ranged between 119.5 to $225.8 \mu \mathrm{g} / \mathrm{g}$ seed with a mean value of $159.6 \mu \mathrm{g} / \mathrm{g}$ seed (Table 4). None of the derived isoflavone isomers showed any significant association with seed longevity.

\section{CONCLUSION}

The antioxidant enzymes viz. SOD, CAT and GR play the pivotal role in maintaining seed longevity. $\alpha-T$, the most bioactive isomer of tocopherols, was negatively associated, where as $\delta$-Twas positively associated with seed longevity; inferred that the role of individual isomerof tocopherols rather than the total tocopherols in maintaining soybean seed longevity.

\section{REFERENCES}

Aebi, H. (1984). Catalase in vitro. Methods in Enzymology. 105: 121-26. Anonymous. (2015). International Rules for Seed Testing. International Seed Testing Association, Bassersdorf, Switzerland.

Beauchamp, C. and Fridovich, I. (1971). Superoxide dismutase: Improved assays and an assay applicable to acrylamidegels. Analytical Biochemistry. 44: 276-87.

Caldas, G.V. and Blair, M.W. (2009). Inheritance of seed condensed tannins and their relationship with seed-coat colour and pattern genes in common bean (Phaseolus vulgaris). Theoretical and Applied Genetics. 119: 131-42.

Castillo, M.D.P., Stenstrom, J. and Ander, P. (1994). Determination of manganese peroxidase activity with 3-methyl-2benzothiazolinone and 3-dimethylamino benzoic acid. Analytical Chemistry. 218: 399-404.

Chen, D., Li, Y., Fang, T., Shi, X. and Chen, X. (2015). Specific roles of tocopherols and tocotrienols in seed longevity and germination tolerance to abiotic stress in transgenic rice. Plant Science. 244: 31-39.

Corbineau, F., Gay-Mathieu, C., Vinel, D. and Come, D. (2002). Decrease in sunflower (Helianthus annuus) seed viability caused by high temperature as related to energy metabolism, 
membrane damage and lipid composition. Physiology Plant. 116: 489-96.

Farahin, A.W., Yusoff, F.M., Nagao, N., Basri,M. and Shariff, M. (2016). Phenolic content and antioxidant activity of Tetraselmistetrathele (west) Butcher 1959 cultured in annular photobioreactor. Journal of Environmental Biology. 37: 631-39.

Gowda, B.C. (2017). MSc thesis seed coat characteristics in relation to seed viability and vigour in soybean. IARI New Delhi.

Hameed, A., Rasheed, A., Gul, B. and Khan, M.A. (2014). Salinity inhibits seed germination ofperennial halophytes Limoniumstocksii and Suaedafruticosa by reducing water uptake and ascorbate dependent antioxidant system. Environment and Experimental Botany. 107: 32-38.

Hosamani,J., Dadlani, M., Santha, I.M., Kumar, M.A. and Jacob, S.R. (2013). Biochemical phenotyping of soybean [Glycine $\max ($ L.) Merill] genotypes to establish the role of lipid peroxidation and antioxidant enzymes in seed longevity. Agriculture Research. 2(2): 119-26.

Jiang, Q. (2014). Natural forms of vitamin E: metabolism, antioxidant, and anti-inflammatory activities and their role in disease prevention and therapy. Free Radical Biology and Medicine. 72: 76-90.

Justice, O.L. and Bass, L.N. (1978). Principles and Practices of Seed Storage. Handbook 506. Science and Education Administration, USDA, Washington D.C., USA. pp. 289.

Kamal-Eldin, A. and Appelqvist, L.A. (1996). The chemistry and antioxidant properties of tocopherols and tocotrienols. Lipids. 31: 671-701.

Kim, H.J. (2014). Effect of $\alpha-, \beta-, \gamma$ - and $\delta$-tocotrienol on the oxidative stability of lard. Journal of American Oil Chemists' Society. 91: 777-82.

Lamichaney, A., Katiyar, P.K., Natarajan, S. and Sripathy, K.V. (2016). Relationship among some seed characters, laboratory germination and field emergence in chickpea (Cicer arietinum L.) genotypes differing in testa colour. Journal of Food Legumes. 29(1): 29-32.

Lamichaney, A. and Katiyar, P.K. (2017). Plant emergence and $T_{50}$ responses of two chickpea cultivar differing in seed coat colour to PEG-osmopriming at sub-optimal temperature. National Academy Science Letters. 40(6): 399-403.

Lamichaney, A., Kudekallu,S., Kamble,U., Sarangapany,N., Katiyar, P.K. and Bohra, A. (2017). Differences in seed vigour traits between desi (pigmented) and kabuli (non-pigmented) ecotypes of chickpea (Cicer arietinum L.) and its association with field emergence. Journal of EnvironmentalBiology. 38(5): 735-42.

Lamichaney, A., Katiyar, P.K., Laxmi, Vijay, Pratap. and Aditya (2018). Variation in pre-harvest sprouting tolerance and fresh seed germination in mungbean (Vigna radiata L.) genotypes. Plant Genetic Resources. 16(5): 437-45.
Lee, J.S., Kwak, J., Yoon, M.R., Lee, J.S. and Hay, F.R. (2017). Contrasting to copherol ratios associated with seed longevity in rice variety groups. Seed Science Research. 27(4): 273-80.

Lee, S.J., Ahn, J.K., Kim, S.H., Kim, J.T., Han, S.J., Jung, M.Y. and Chung, I.M. (2003). Variation in isoflavone of soybean cultivars with location and storage duration. Journal of Agriculture and Food Chemistry. 51(11): 3382-89.

Lehner, A., Mamadou, N., Poels, P., Come, D., Bailly, C. and Corbineau, F. (2008). Changes in soluble carbohydrates, lipid peroxidation and antioxidant enzyme activities in the embryo during ageing in wheat grains. Journal of Cereal Science. 47: 555-65.

Liebler, D.C. (1993). The role of metabolism in the antioxidant function of vitamin E. Critical Reviews in Toxicology. 23: 147-69.

Ohkawa, H., Ohishi, N. and Yagi, K. (1979). Assay for lipid peroxides in animal tissues by thiobarbituric acid reaction. Analytical Biochemistry.95: 351-58.

Priestley, D.A., McBride, M.B. and Leopold, C. (1980). Tocopherol and organic free-radical levels in soybean seeds during natural and accelerated aging. Plant Physiology. 66: 71519.

Saha, S., Walia, S., Kundu, A. and Pathak, N. (2013). Effects of mobile phase on resolution of the isomers and homologues of tocopherols on a triacontyl stationary phase. Analytical BioAnalytical Chemistry. 405(28): 9285-95.

Sattler, S.E., Gilliland, L.U., Magallanes-Lundback, M., Pollard, M. and Della Penna, D. (2004).Vitamin E is essential for seed longevity and for preventing lipid peroxidation during germination. The Plant Cell.16: 1419-32.

Simontacchi, M., Caro, A., Fraga,C.G. and Puntarulo, S. (1993). Oxidative stress affects alpha-tocopherol content in soybean embryonic axes upon imbibition and following germination. Plant Physiology. 103: 949-53.

Singh, R.K. and Ram, H.H. (1986).Inheritance study of soybean seed storability using an accelerated aging test. Field Crops Research. 13: 89-98.

Smith, I.K., Vierheller, T.L. and Thorne, C.A. (1988). Assay of glutathione reductase in crude tissue homogenates using 5, 52 dithiobis (2-nitrobenzoic acid). Analytical Biochemistry. 175: 408-13.

Sooganna, Jain, S.K., Bhat, K.V., Lamichaney Amrit. and Lal, S.K. (2016). Characterization of soybean (Glycine max) genotypes for seed longevity using SSR markers. Indian Journal of Agricultural Science. 86(5): 605-10.

Wang, Q., Ge, X., Tian, X., Zhang, Y., Zhang, J. and Zhang, P. (2013). Soy isoflavone: The multipurpose phytochemical. Biomedical Reports. 1(5): 697-701. 